\title{
CONIFEROUS WOODS FROM THE UPPER CRETACEOUS OF PATAGONIA, ARGENTINA
}

\author{
Georgina M. DEL FUEYO
}

División Paleobotánica. Museo Argentino de Ciencias Naturales "Bernardino Rivadavia". Av. Angel Gallardo 470.(1405) Buenos Aires. Argentina.

Del Fueyo, G.M. 1998. Coniferous woods from the Upper Cretaceous of Patagonia, Argentina. Revista Española de Paleontología, 13 (1), 43-50. ISSN 0213-6937.

\begin{abstract}
Silicified wood is figured and described from the upper part of the Upper Cretaceous Allen Formation of Río Negro Province, Argentina. The good preservation as well as the presence of roots in some of the logs suggest they were transported for short distances. Two new species are described, Circoporoxylon gregussii and Podocarpoxylon garciae. The characters of the wood remains, together with the comparison made between living and fossil woods, indicate that both taxa belong to the Podocarpaceae. Associated plants (palms, cycads) and the anatomical structure of the woods suggest that they developed under a fairly equable climate; growth rings are not well marked.
\end{abstract}

Keywords: Conifers, Podocarpaceae, silicified wood, Allen Formation, Upper Cretaceous, Río Negro Province, Argentina.

\section{RESUMEN}

En este trabajo se estudian troncos silicificados provenientes del Cretácico Superior tardío de la Provincia de Río Negro, Argentina. Su buena conservación, así como la presencia de raices en algunos de los especímenes sugieren que el transporte no fue muy grande desde su lugar de origen. Se describen dos nuevas especies: Circoporoxylon gregussii y Podocarpoxylon garciae. Las características del leño junto con las comparaciones realizadas con otras especies fósiles y actuales sugieren que ambos taxa pertenecen a la familia Podocarpaceae. Plantas fósiles asociadas (palmeras y cycadales) y los caracteres anatómicos de las maderas indican que los árboles se desarrollaron en condiciones de clima templado y cálido, sin grandes diferencias estacionales como lo demuestran sus anillos de crecimiento poco marcados.

Palabras clave: Coníferas, Podocarpaceae, troncos silicificados, Formación Allen, Cretácico Superior, Provincia de Río Negro, Argentina.

\section{INTRODUCTION}

Patagonia is widely known for its abundance and variety of fossil plants, including a good representation of conifer remains. Within this group petrified wood is rather abundant throughout the Mesozoic and Tertiary. The Jurassic Petrified Forest of Cerro Cuadrado in Santa Cruz Province is justly famous for the large stumps that are supposed to belong to the Araucariaceae (Wieland, 1935; Calder, 1953). The Upper Triassic Uspallata Petrified Forest in Mendoza Province, discovered by Darwin in 1835 is also related to the Aracauriaceae (Rusconi, 1938; Fossa-Mancini, 1941). The Rhaetic Agua de la Zorra Fossil Forest of the same Province is mainly composed of Araucariaceae as well (Rusconi, 1941; Brea, in press). Isolated coniferous fossil wood of Triassic and
Tertiary age, has also been mentioned from several fossiliferous beds in Patagonia (Mansfeld, 1948; Petriella, 1972; Zamuner and Artabe, 1994).

Fossil wood from the Bajo de Santa Rosa locality was cited first by Doering (1882) and later by Wichmann $(1919,1927)$ but they did not make an anatomical study. Bajo de Santa Rosa has several levels with petrified logs belonging to palms (Ancibor, 1995), cycads and conifers. The latter are the most abundant: approximately one hundred specimens have been counted in the area of outcrop. The coniferous trunks are 6 to $8 \mathrm{~m}$ long and up to $80 \mathrm{~cm}$ in diameter. All are decorticated and only a few specimens show roots.

The purpose of this paper is to describe the wood anatomy of these trunks in order to establish their botanical affinities, and so to gain a better understanding 


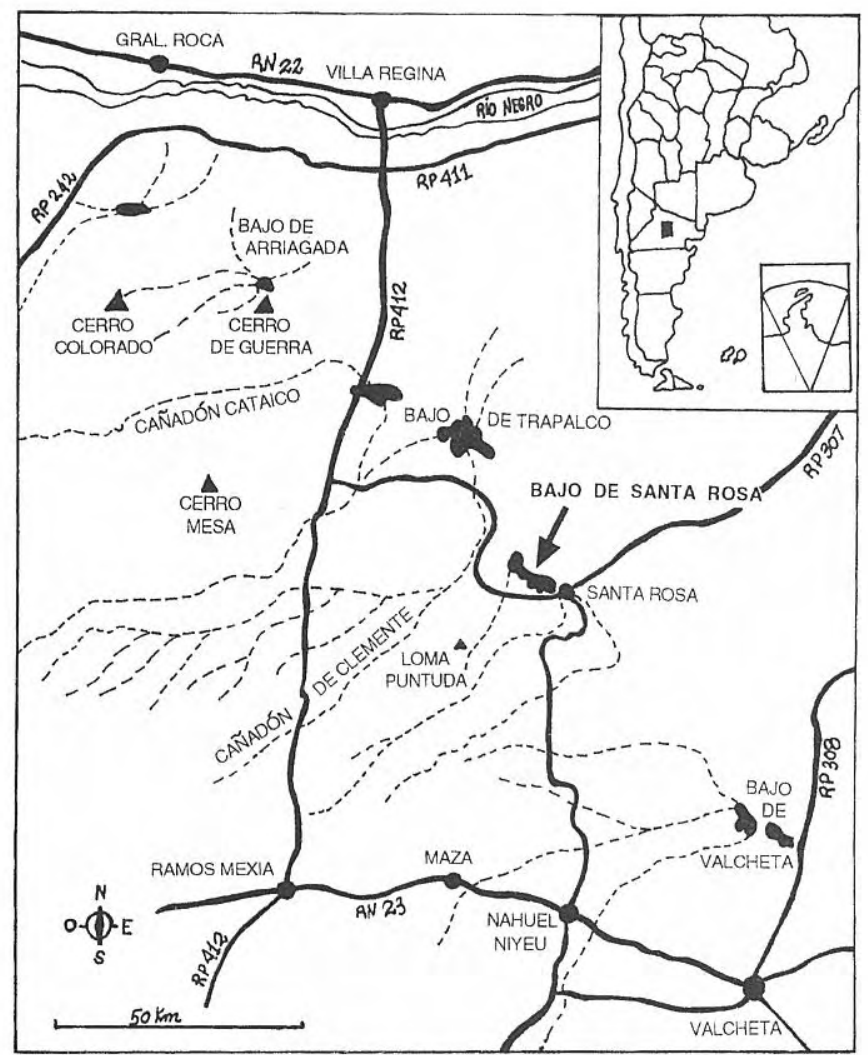

Figure 1. Map of Argentina showing the location of Santa Rosa.

of the nature and composition of the Upper Cretaceous flora of Patagonia.

\section{GEOLOGICAL BACKGROUND}

The material was collected at the Bajo Santa Rosa locality $\left(40^{\circ} \mathrm{S}-60^{\circ} \mathrm{W}\right.$ approximately), $100 \mathrm{~km}$ Northwest of Valcheta township, Río Negro Province in northern Patagonia, Argentina (Fig. 1). Stratigraphic studies made by Andreis et al. (1991) and Andreis (1996) show that the Allen Formation is a continental to deltaic shallow marine succession. This Formation lies unconformably over the Bajo de la Carpa continental succession (Santonian), and is conformably covered by shallow marine deposits of the Roca Formation (Danian). In other areas located $200 \mathrm{~km}$ to the NW, at Lago Pellegrini, between Allen and Roca formations, another marine unit, the Jagüel Formation, composed by yellowish to brown-yellowish silstones and claystones appears. Together, the Allen and Jagüel
Formation constitute the Malargüe Group, dated as late Campanian-early to middle (or late?) Maastrichtian, i.e. Upper Cretaceous. The basal part of the Allen Formation includes braided fluvial deposits. They are constituted by medium to coarse cross-bedded sandstones and polymictic conglomerates, composed of volcanics, quartz feldspars and calcrete horizons of phreatic origin (Andreis, 1996). The petrified material studied here was recovered from several fossiliferous horizons related to these fluvial sediments. The presence of roots in some logs as well as their good preservation suggest that the trunks were transported for short distances from their site of growth.

\section{MATERIAL AND METHODS}

The specimens are silicified. Thin sections were made of transverse, tangential and radial views of the wood. Specimens and microscope slides are lodged in the Palaeobotanical and Entomological collections of the Museum of Natural Science "Bernardino Rivadavia" of Buenos Aires, under: BA PB, BA PBPm. and MACN Ent., respectively.

\section{SYSTEMATIC DESCRIPTIONS}

\section{CLASS CONIFEROPSIDA Gifford and Foster 1989 ORDER CONIFERALES Gifford and Foster 1989 Family Podocarpaceae Page 1990 Genus Circoporoxylon Kräusel 1949}

Type species: Circoporoxylon priscum (Prill) Kräusel and Jain 1963.

\section{Circoporoxylon gregussii nov. sp. Pl. I, figs. 1-7}

\section{Diagnosis}

Growth rings marked only slightly; wide rays; tracheids in cross section 37-55 $\mu \mathrm{m}$ in diameter, wall 4-5 $\mu \mathrm{m}$ thick, bordered pits on radial walls in a single row or two opposite rows, pits separated, circular, 15-20 $\mu \mathrm{m}$ in diameter, inner aperture rounded, $5 \mu \mathrm{m}$ in diameter; pits on tangential walls of the tracheids rare; cross-field pits one or two, simple, circular to oval in shape, 11-13 $\mu \mathrm{m}$ by 7-9 $\mu \mathrm{m}$; rays homocellular, uniseriate, $1-15$ cells high, biseriate, 6-38 cells high, and partially biseriate, 5-50 cells high; parenchyma ray cells $22 \mu \mathrm{m}$ wide and $26 \mu \mathrm{m}$ long; axial parenchyma present.

\section{Plate I}

Circoporoxylon gregussii nov. sp. Holotype.

1 Transverse section showing a growth ring $x 40$. BA PB Pm 141.

2 Details of late and early wood tracheids x 125 . BA PB Pm 141.

3 Tangential section of uni- and multiseriate rays $\mathrm{x} 125$. BA PB Pm 79.

4-5 Radial section showing two opposite rows of pits in the tracheids. Note axial parenchyma (arrow) x 125 . BA PB Pm 80.

6-7 Cross-fields with one simple pit x 200. BA PB Pm 80.

All scale bars $=100 \mu \mathrm{m}$. 
Plate I


Revista Española de Paleontología, 13 (1), 1998. 
Holotype: BA PB: 870; BA PBPm: 79, 80, 141. (Pl. I, figs. 1-7).

Paratypes: BA PB: $845,865,867,868,872,873,955$; BAPBPm: 73-77, 83-85, 95-97, 144-147, 150-152, 162-164.

Locality: Santa Rosa ( $\left.40^{\circ} \mathrm{S}-60^{\circ} \mathrm{W}\right), 100 \mathrm{~km}$ Northwest of Valcheta township, Río Negro Province, Argentina.

Stratigraphic position: Allen Formation. Upper Cretaceous (late Campanian-early to middle Maastrichtian).

Etymology: Dedicated to the late Pál Greguss, for his invaluable contributions on living and fossil gymnosperm woods.

\section{Note}

When Kräusel (1949) described Circoporoxylon, he did not name a type species. Later, Kräusel and Jain (1963) established C. priscum Prill as the type. However, Andrews (1970) designated C. goepperti Conwentz as type. The latter is based on Argentinian material that is missing from the Palaeobotanical collection at Córdoba University (Archangelsky, personal communication). I follow the choice made by the author of the genus.

\section{Description}

The studied specimens are at least $12 \mathrm{~cm}$ in diameter and $18 \mathrm{~cm}$ long. The cross section (Plate I, fig. 1) shows growth rings marked slightly by $1-2$ layers of fibertracheids. Growth rings range from $0.4 \mathrm{~mm}$ up to $3 \mathrm{~mm}$ in width. The rays are conspicuous, full of contents and separated by 3 to 5 rows of tracheids. The late wood tracheids are rectangular-flattened and the early wood tracheids are polygonal. The diameter of the tracheids is $50 \mu \mathrm{m}$ on the average, and the wall is $5 \mu \mathrm{m}$ thick (Plate I, fig. 2). Axial parenchyma is frequent and diffuse (Plate I, fig. 4).

In tangential section the rays are: uniseriate and 1-15 cells high, most commonly $2-5$ cells high; biseriate, 6-38 cells high, most commonly 18 cells high, and partially biseriate, 5-50 cells high, most commonly 15 cells high. Partially triseriate rays, 32 cells high are rare. Parenchyma cells are not pitted and approximately barrel-shaped, $22 \mu \mathrm{m}$ and $26 \mu \mathrm{m}$ long (Plate I, fig. 3). Pits on the tangential walls of tracheids are uncommon; where present, they are circular and occur in one single row.

The radial section (Plate I, figs. 4, 5) shows homocellular rays with rectangular cells, $23 \mu \mathrm{m}$ wide and $110 \mu \mathrm{m}$ long. The arrangement of the pits on the radial walls of the tracheids is in one separate row and in two opposite separate rows. They are circular in outline, $17 \mu \mathrm{m}$ in diameter. The inner aperture is circular, $5 \mu \mathrm{m}$ in diameter. The crassules are common. Cross-field pits are simple, elliptical to circular, $12 \mu \mathrm{m}$ by $8 \mu \mathrm{m}$ in the first case and $11 \mu \mathrm{m}$ in diameter in the second. One to two pits per cross-field are present, one being the most common (Plate I, figs. 5, 7).

\section{Comparisons}

The distinctive feature of this wood is its cross-field pitting. Among living conifers, large simple pits in the cross-fields occur in the Pinaceae, in many species of Pinus, and they are common in the Sciadopityaceae and Phyllocladaceae. Within the Podocarpaceae they occur in a few species of Dacrydium, and in Microcachrys, Acmopyle, Microstrobus and Nageia (Greguss, 1955, 1972).

The present wood agrees with the diagnosis of the genus Circoporoxylon which has been established by Kräusel (1949) to include fossil woods with simple circular or oval cross-field pits (also called "Eiporen" or "egg pores"). None of the known species of Circoporoxylon from the Mesozoic are comparable to Circoporoxylon gregussii. C. sewardi (Sahni, 1920) Kräusel 1949, from the Jurassic of Australia differs by having low rays up to 8 cells high. In C. shanense (Sahni, 1938) Kräusel 1949 from the Jurassic of India, the differences are more accentuated: the axial parenchyma is absent and the rays are uniseriate, 4 cells high. Kräusel and Jain (1963) reported $C$. amarjolense from the Jurrasic of India with uniseriate to biseriate rays 1 to 15 cells high, and crossfields with simple circular pits, 5 to $7 \mu \mathrm{m}$ in diameter without axial parenchyma.

Several woods of this genus have been described from the Cretaceous, having some features in common. Circoporoxylon mcgeei (Knowlton) Kräusel 1949 from the Lower Cretaceous of the United States has uniseriate rays, 2 to 49 cells high and 1 to 2 oval simple pits in the cross-field. Two species of Circoporoxylon have been studied from England. C.woburnense (Stopes, 1915) Kräusel 1949 presents uniseriate to slightly biseriate rays, 1 to 25 cells high, with one large circular or oval simple pit per cross-field. C. hortii (Stopes, 1915) Kräusel 1949 is similar by the presence of axial parenchyma and isolated round bordered pits in the tracheids, but differs by having extraordinary high and multiseriate rays, 70 to 80 cells high and large single circular pits in the crossfields. C. goeppertii (Conwentz, 1885) Kräusel 1949, from the Oligocene of Argentina, is based on only a small specimen, $2.5 \mathrm{~cm}$ long and $3.2 \mathrm{~cm}$ in diameter. The differences are shown by the uniseriate rays, 1 to 25 cells high, and the cross-fields with round simple pits of 29.5 $\mu \mathrm{m}$ in diameter.

\section{Plate II}

Podocarpoxylon garciae nov. sp.

1 Transverse section showing an indistinctly marked growth ring x 125. Holotype, BA PB Pm 120.

2 Details of early wood tracheids x 320 . Holotype, BA PB Pm 120.

3 Tangential section showing uniseriate rays x 200 . Paratype, BA PB Pm 186.
4 Radial section showing a single row of pits in the tracheids x 125. Holotype, BA PB Pm 121.

5 Detail of radial pits x 200. Holotype, BA PB Pm 121.

6 Ray cell with one cross-field pit $x$ 400. Paratype, BA PB Pm 166.

All scale bars $=100 \mu \mathrm{m}$. 

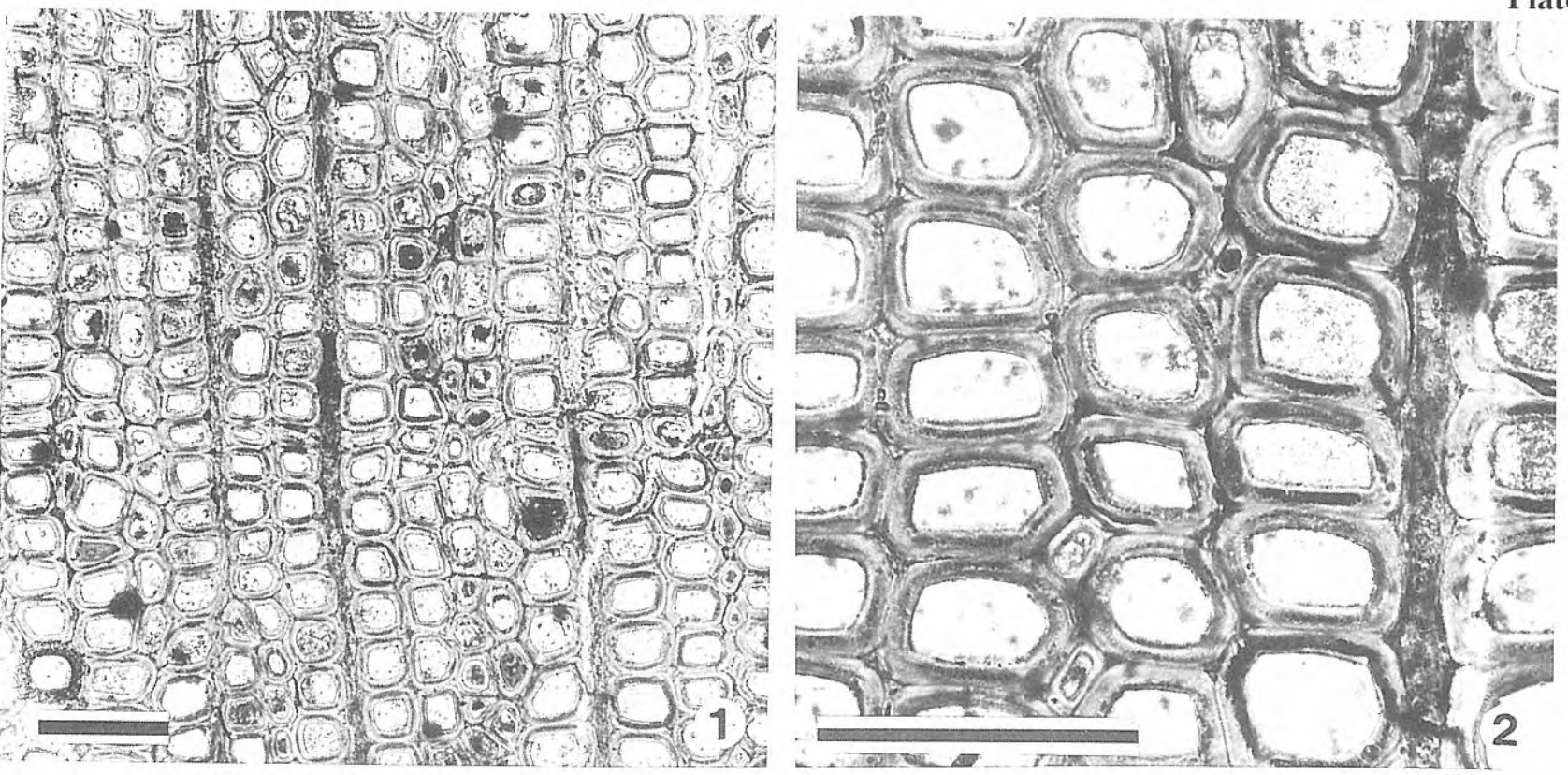

Plate II
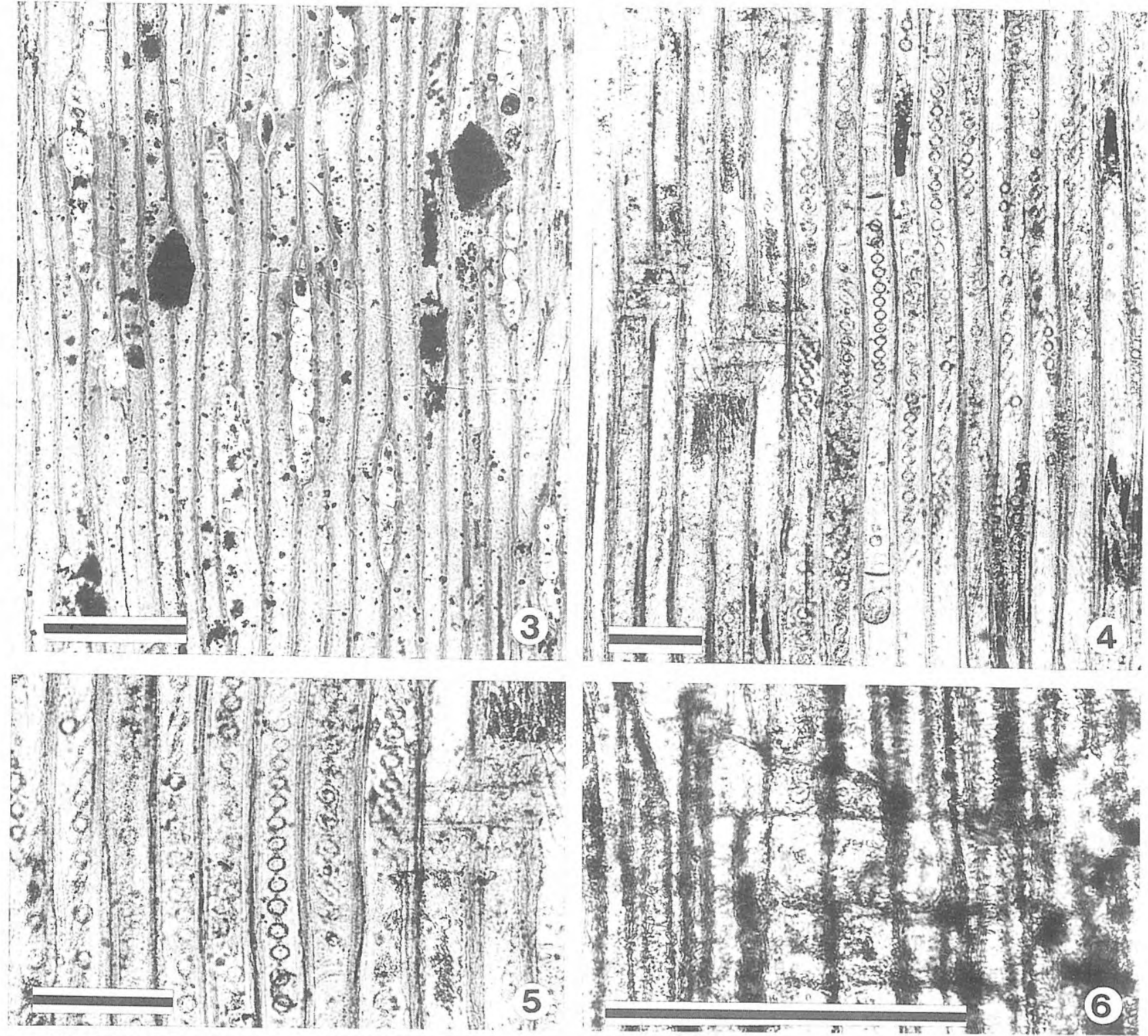

Revista Española de Paleontología, 13 (1), 1998. 


\section{Genus Podocarpoxylon Gothan 1904}

Type species: Podocarpoxylon juniperoides Gothan, in Gagel 1904.

\section{Podocarpoxylon garciae nov. sp. Pl. II, figs. 1-6}

\section{Diagnosis}

Growth rings indistinctly marked; tracheids in cross section $28-40 \mu \mathrm{m}$ in diameter; wall 6-8 $\mu \mathrm{m}$ thick; bordered pits on radial walls in a single row, pits separated, circular, 8-14 $\mu \mathrm{m}$ in diameter, inner aperture circular to ovate?; cross-field pits one or two, circular, $3-5 \mu \mathrm{m}$ in diameter; rays homocellular, uniseriate and 1-15 cells high (2-3 most common), rays separated by 4-10 rows of tracheids, parenchyma of rays with unpitted walls; axial parenchyma scarce; intercelular axial spaces frequent.

Holotype: BA PB: 842; BA PB Pm: 120, 121, 122. (Pl. II, figs. 1, 2, 4, 5).

Paratypes: BA PB: 839, 846, 847, 849, 877, 931, 980, 989, 990, 991. MACN. Ent.: 53814.2.(Pl. II, figs. 3, 6). BA PB Pm: 92-94, 98, 99, 119-125, 129-131, 138-140, 156-158, 165, 167, 168, 170, 177-186, 199.

Locality: Santa Rosa $\left(40^{\circ} \mathrm{S}-60^{\circ} \mathrm{W}\right), 100 \mathrm{~km}$ Northwest of Valcheta township, Río Negro Province, Argentina.

Stratigraphic position: Allen Formation. Upper Cretaceous (late Campanian-early to middle Masstrichtian).

Etymology: Dedicated to the late Marcelo García and his family, owners of the locality; they kindly donated the studied specimens which they helped to collect.

\section{Description}

The diameter of the studied material is c. $20 \mathrm{~cm}$ and its length $37 \mathrm{~cm}$. The transition from early wood to late wood is not well marked (Plate II, fig. 1). Annual growth rings are distinguished by 1 - 4 layers of late wood tracheids. Growth rings range from $0.5 \mathrm{~mm}$ up to $1 \mathrm{~mm}$ in width. The rays are separated by 4-10 rows of tracheids, with an average separation of 7 rows. Late wood tracheids are rectangular in cross section while those of the early wood are polygonal. The diameter of the tracheids is $34 \mu \mathrm{m}$ on the average, and the wall is about $6 \mu \mathrm{m}$ thick. Intercellular axial spaces are frequent (Plate II, fig. 2).

In tangential section the rays are uniseriate, rarely biseriate, ranging from 1-15 cells, most commonly $2-3$ cells high. Each of the ray parenchyma cells is elongate, commonly as a narrow ellipse $24 \mu \mathrm{m}$ high and $15 \mu \mathrm{m}$ wide. The tangential and transverse walls of the parenchyma cells are smooth (Plate II, fig. 3). The length of the tracheids is difficult to measure due to poor preservation. The trabeculae are present, especially abundant in specimen BA PB 839. Axial parenchyma is scarce and diffuse.

The radial section shows homocellular rays, and the parenchyma cells are $25 \mu \mathrm{m}$ wide and $79 \mu \mathrm{m}$ long. The bordered pits are confined to the radial walls of the tracheids. They are placed in single rows which are well separate; in a few tracheids the pits are in two opposite to subopposite rows. The pits are circular in outline and $10 \mu \mathrm{m}$ in diameter. The inner aperture is circular to ovate and $3 \mu \mathrm{m}$ in diameter (Plate II, figs. 4, 5). The cross-field pits are difficult to characterise due to poor preservation. One pit per cross-field is the most common condition, but a few sections have 2 per cross-field (Plate II, fig. 6). The pits are circular, $2.8 \mu \mathrm{m}-5.6 \mu \mathrm{m}$ in diameter. The inner aperture is almost invariably not preserved, but in specimen MACN Ent. 53814 1,2 it appears to be circular, $1.4 \mu \mathrm{m}$ in diameter.

\section{Comparisons}

The structure of this wood corresponds most closely to that of Podocarpoxylon Gothan (in Gagel, 1904), which is characterised by a few small cross-field pits, walls of the ray cells smooth, axial parenchyma scarce and abietinean radial pitting in tracheids.

Living species of the Podocarpaceae show these characters, especially within the genus Podocarpus (Greguss, 1955, 1972).

A large number of Mesozoic and Tertiary species of Podocarpoxylon have been described. The comparison with $P$. garciae will be focused on the species from Gondwana.

P. indicum (Bhardway, 1953) Kräusel 1949 from the Jurassic of India differs because is devoid of axial parenchyma, and the rays are uniseriate, 1 to 5 cells high. Another Jurassic species from India, $P$. godaverianum (Sahni, 1931) Kräusel 1949 has abundant axial parenchyma and 2 to 6 pits in the cross-field. These differences are also shown by P. walkomi (Sahni, 1920) Kräusel 1949 from the Jurassic of Australia, by having 2 to 5 pits in the cross-field, abundant parenchyma and uniseriate rays up to about 20 cells high. Two Podocarpoxylon sp. have been studied from the Upper and Lower Cretaceous of Antarctica by Torres and Lemoigne (1989) and Francis and Coffin (1992), respectively. The specimens can be distinguished from P.garciae by: the former has uniseriate rays 1 to 18 cells high, abundant axial parenchyma and 1 to 3 pits per cross-field. The latter is characterised by uniseriate rays, 2 to 9 cells high, 1 to 3 pits in the cross-field and without axial parenchyma. Kräusel (1924) described $P$. dusenii from the Tertiary of Santa Cruz Province, Argentina, which differs by having uniseriate rays, 1 to 20 cells high and axial parenchyma absent. Also, P. aparechymatosum (Gothan,1908) from the Tertiary of Antarctica does not posses axial parenchyma.

Tortorelli (1941) studied a not very well preserved specimen of unknown age from Valcheta township (Río Negro Province), and assigned it erroneously to Ginkgo. Even though there is no data about the radial section, his material shows a close similarity with specimen BA PB.842 in transverse section, and with specimen BA PB. 839 in tangential section (figs. 1 and 2, respectively, of Tortorelli). The difference is shown by the high occurrence of pits in two rows on radial walls of tracheids. 
The xylem of specimen MACN. Ent. 53814.2 shows several borings, that have been described as Xylonichnus trypetus, a buprestid (Genise, 1995).

\section{CONCLUDING REMARKS}

A characteristic shared by all genera of the Podocarpaceae is that the walls of the ray cells are smooth and thin, and that they possess the so-called abietinean type of radial pitting, where the pits are circular, separated in single rows or in two opposite rows. Also, most genera have as a rule a single pit in the crossfield. However, the ray structure is rather heterogenous. Some genera have the typical podocarpoid pitting in the cross-field with pits circular or elliptical in outline, small or sometimes large, whilst others present the circoporoid type that frequently fills the entire field (Greguss, 1955). The woods described for Podocarpoxylon garciae and Circoporoxylon gregussii show the character that allow them to be included within the Podocarpaceae.

Insect trace fossils from Allen Formation are represented by buprestids in the coniferous logs, as well as by termites in cycad stems and beetles in palm stems and palm fruits (Genise, 1995). This shows plant-insect interaction for very Late Cretaceous time in Patagonia.

Three Palmoxylon species (Ancibor, 1995) and cycads (under study), also described from the same formation, indicate a temperate and warm climate, a condition that is also suggested by the poorly marked growth rings of P.garciae and C.gregussii.

The Podocarpaceae are mostly found in Gondwana, where they have an abundant record (Hill, 1995). The two new fossil woods described here point out that Patagonia played an important role in the history and development of a family that still has living representatives in the area.

\section{ACKNOWLEDGEMENTS}

The author is grateful to Dr. Sergio Archangelsky for his help and discussion of the manuscript, and to Drs Elena Ancibor, Renato Andreis, and Jorge Wright for their useful suggestions. Also to the reviewers Drs Carmen Diéguez and Robert Wagner for their comments, which improved the paper.

\section{REFERENCES}

Ancibor, E. 1995. Palmeras fósiles del Cretácico Tardío de la Patagonia Argentina (Bajo de Santa Rosa, Río Negro). Ameghiniana, 32 (3), 287-299.

Andreis, R. 1996. The Cretaceous-Tertiary boundary around the Somuncurá Massif (Northern Patagonia, Argentina): Considerations about the Los Alamitos and Allen Formations. In: News of the First Annual Conference of IGCP Proyect 381 (SAMCI), Salvador, Bahía, Brazil, 5, 12-14.
Andreis, R., Ancibor, E., Archangelsky, S., Artabe,A., Bonaparte, J. y Genise, J. 1991. Asociación de vegetales y animales en estratos del Cretácico Tardío del Norte de Patagonia. Ameghinina, 28 (1-2), 201-202.

Andrews, H.N. 1970. Index of generic names of fossil plants 1820-1965. Geological Survey Bulletin, 1300, 1-354.

Bhardway, D.C. 1953. Jurassic woods from the Rajmahal Hills, Bihar. The Palaeobotanist, 2, 59-70.

Brea, M. (in press). Una nueva especie fósil del género Araucarioxylon Krauss 1870, emend. Maheshwari 1972 del Triásico de Agua de la Zorra, Uspallata, Mendoza, Argentina. Ameghiniana.

Calder, M.G. 1953. A coniferous petrified forest in Patagonia. Bulletin of the British Museum (Natural History) Geology, 2, 99-138.

Conwentz, H. 1885. Sobre algunos árboles fósiles del Río Negro. Boletín de la Academia Nacional de Ciencias, 7, 435-456.

Doering, D.D. 1882. Informe Oficial de la Comisión Científica de la Expedición al Río Negro. III: Geología, Buenos Aires, 530 pp.

Fossa-Mancini, E. 1941. Los bosques petrificados de Argentina. Notas del Museo de la Plata. Geología, 6(12), 59-92.

Francis, J.E. and Coffin, M.F. 1992. Cretaceous fossil wood from the Raggatt Basin, southern Kerguelen Plateau (Site 750). In: Proceedings of the Ocean Drilling Program, Scientific Results (Eds. S.W. Wise and R. Schlich), Texas, 120, 273-280.

Gagel, C. 1904. Über einige Bohrergebnisse und ein neues pflanzenführendes Interglazial aus der Gegend von Elmshorn. Preussische Geologische Landesanstalt und Bergakademie, 25, 246-281.

Genise, J. 1995. Upper Cretaceous trace fossils in permineralized plant remains from Patagonia, Argentina. Ichnos, 3, 287-299.

Gothan, W. 1908. Die Fossilen Hölzer von der Seymour und Snow Hill-Insel. In: Wissenschaftliche Ergebnisse der Schwedischen Südpolar-Expedition 1901-1903 (Ed. O. Nordenskyöld), Stockholm, 3(8), 1-33.

Greguss, P. 1955. Identification of living gymnosperms on the basis of xylotomy. Akadémiai Kiadó, Budapest, 263 pp.

Greguss, P. 1972. Xylotomy of the living conifers. Akadémiai Kiadó, Budapest, 329 pp.

Hill, R.S. 1995. Conifer origin, Evolution and diversification in the Southern Hemisphere. In: Ecology of the Southern Conifers (Eds. N.J. Enright and R.S. Hill). Melbourne University Press, Victoria, 10-29.

Kräusel, R. 1924. Beiträge zur Kenntnis der fossilen Flora Südamerikas. I. Fossile Hölzer aus Patagonien und benachbarten Gebieten. Arkiv För Botanik, 19(9), 1-35.

Kräusel, R. 1949. Die fossilen Koniferen-Hölzer (unter Ausschluss von Araucarioxylon Krauss). II. Kritische Untersuchungen zur Diagnostik lebender und fossiler Koniferen-Hölzer. Palaeontographica, 89B, 83-203.

Kräusel, R. and Jain, K.P. 1963. New fossil coniferous wood from the Rajmahal Hills, Bihar, India. The Palaeobotanist, 12, 59-67. 
Mansfeld, F. 1948. Los bosques petrificados y los principales yacimientos de troncos fósiles en Santa Cruz. Argentina Austral, 201, 4-15.

Page, C.N. 1990. Pinatae. In: The families and genera of vascular plants (Ed. K. Kubitzki). Springer-Verlag, Berlin, 290-361.

Petriella, B. 1972. Estudio de maderas petrificadas del Terciario Inferior del area Central de Chubut (Cerro Bororó). Revista del Museo de La Plata (Nueva Serie) Sección Paleontología, 6, 159-254.

Rusconi, C. 1938. Las araucarias fósiles de Uspallata. Revista Geográfica Americana, 9(57), 394-398.

Rusconi, C. 1941. Bosques petrificados de Mendoza. Anales de la Sociedad Científica Argentina, 132, 80-96.

Sahni, B. 1920. Petrified wood remains from the Queensland Mesozoic and Tertiary Formations. Queensland Geological Survey, 267, 1-48.

Sahni, B. 1931. Revision of Indian fossil plants. Part II. Coniferales. (b. Petrifications). Memoirs of the Geological Survey of India. Palaeontologia Indica (N.S), 11, 51-124.

Sahni, B. 1938. A Mesozoic coniferous wood (Mesembrioxylon shanense, sp.nov.) from the southern Shan States of Burma. Records of the Geological Survey of India, 71(4), 380-388.

Stopes, M. 1915. Catalogue of the Mesozoic Plants in the
British Museum. The Cretaceous Flora. Part II. Lower Greensand (Aptian). Plants of Britain. British Museum of Natural History, London, 360 pp.

Torres, T. y Lemoigne, Y. 1989. Hallazgos de maderas fósiles de Angiospermas y Gimnospermas del Cretácico Superior de Punta Williams, isla Livingston, islas Shetland del Sur, Antarctica. Serie Científica del Instituto Antarctico Chileno, 39, 9-29.

Tortorelli, L. 1941. Paleomicroxilografía de una especie Patagónica. Anales de la Sociedad Científica Argentina, 131, 111-122.

Wichmann, R. 1919. Contribución a la Geología de la Región comprendida entre el Río Negro y Arroyo Valcheta. Anales del Ministerio de Agricultura de la Nación. Sección Geología, Mineralogía y Minería, 13(4), 1-45.

Wichmann, R. 1927. Sobre la facies lacustre Senoniana de los estratos con dinosaurios y su fauna en los territorios del Río Negro y del Chubut. Boletín de la Academia Nacional de Ciencias de Córdoba, 30, 383- 405.

Wieland, G.R. 1935. The Cerro Cuadrado petrified forest. Carnegie Institution of Washington, Washington, 449 pp.

Zamuner, A. y Artabe, A. 1994. Estudio de un leño fósil Protocircoporoxylon marianaensis n.sp. de la Formación Paso Flores (Neotriásico), Provincia de Río Negro, Argentina. Ameghiniana, 31(3), 203-207.

Manuscrito recibido: 27 de enero, 1997 Manuscrito aceptado: 13 de septiembre, 1997 